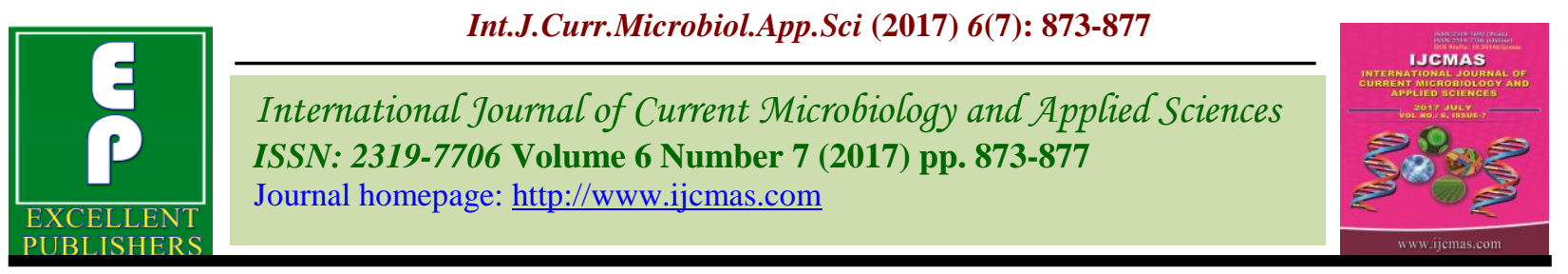

Original Research Article

https://doi.org/10.20546/ijcmas.2017.607.107

\title{
Studies on Variability, Heritability and Genetic Advance in Some Quantitative Characters in Bread Wheat (Triticum aestivum L.)
}

\author{
Deepak Kumar $^{1 *}$, R.K. Srivastava ${ }^{1}$, P.K. $\operatorname{Yadav}^{1}$, Ashwani Kumar ${ }^{2}$ and R.S. Yadav \\ ${ }^{1}$ Department of Genetics and Plant Breeding, NDUA\&T, Kumarganj, \\ Faizabad- 224229 (UP), India \\ ${ }^{2}$ U.P. Council of Agricultural Research (UPCAR), Luvknow- 226010 (UP), India \\ ${ }^{3}$ Department of Botany, KKPG College, Etawah (UP), India \\ *Corresponding author
}

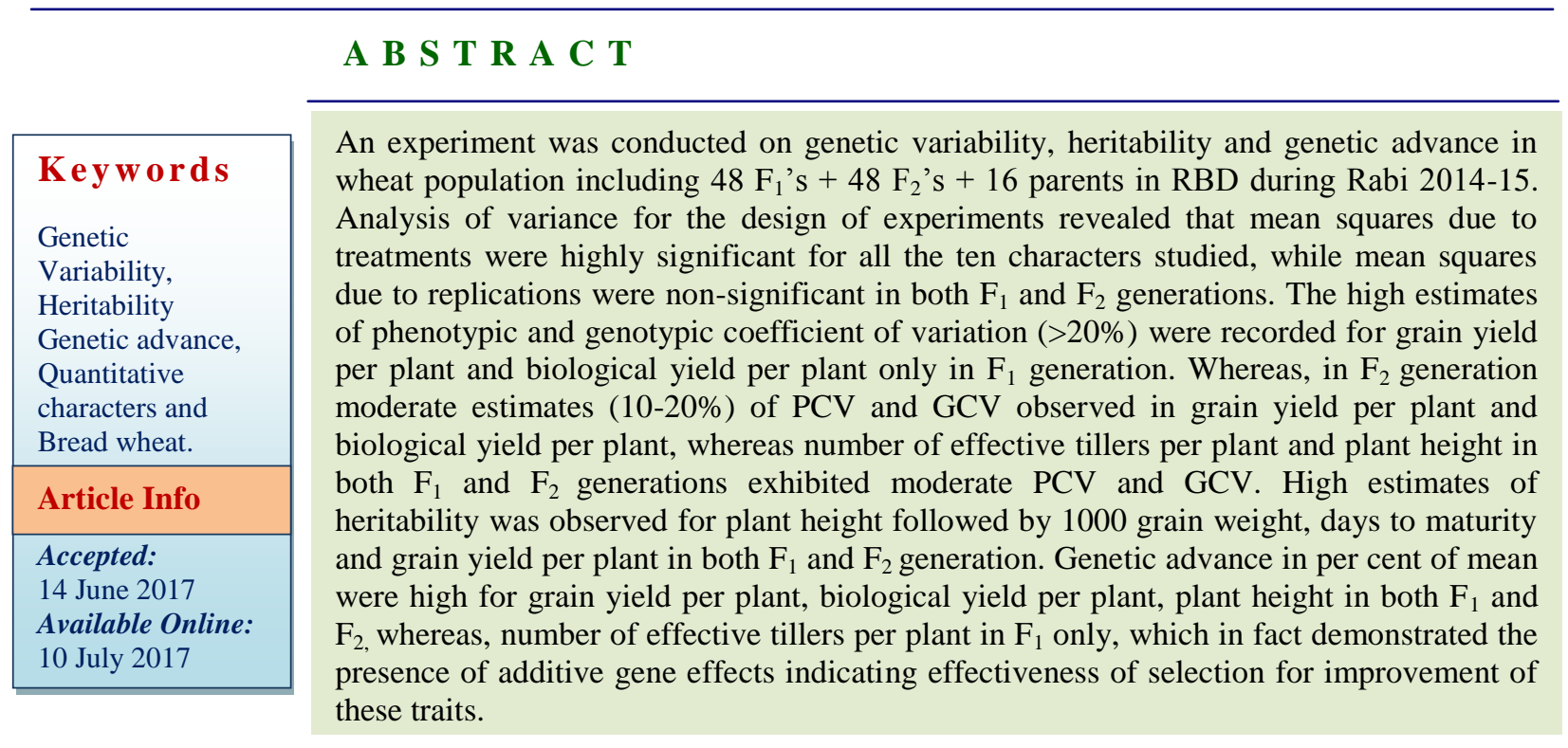

\section{Introduction}

Wheat (Triticum aestivum L.; $2 \mathrm{n}=42$ ) is a self-pollinated crop belong to Poaceae family and one of the most leading cereal of world including India. It is the most important food crop of India and is a main source of protein and energy. In India, wheat is the second most important food crop after rice both in terms of area and production.

It is a $\mathrm{C}_{3}$ plant grown in temperate, irrigated to dry and high-rain-fall areas and in warm, humid to dry, cold environments. The record production in the country during last few years has enabled India to attain the position of being second largest producer of the wheat in the world.

Hence in present investigation an attempt was made to assess the variability on grain yield and biological yield contributing traits which indicating genetic variability i.e. genotypic coefficient variation (GCA), phenotypic coefficient variation (PCV), environment coefficient variation (ECV), heritability in 
broad sense $\left(h^{2} b s\right)$, genetic advance (GA) in per cent of mean.

\section{Materials and Methods}

The experimental material consisted of 112 treatments including $48 \mathrm{~F}_{1}$ 's $+48 \mathrm{~F}_{2}$ 's +16 parents and conducted at Main Experiment Station of Narendra Deva University of Agriculture and Technology, Narendra Nagar (Kumarganj), Faizabad (U.P.) during Rabi, 2014-15 in Randomized Block Design with three replications in a single $\left(\mathrm{F}_{1}\right.$ 's), two (parents) and four rows $\left(\mathrm{F}_{2}\right.$ 's) plot \& of $3 \mathrm{~m}$ length with inter and intra-row spacing of 23 and $10 \mathrm{~cm}$, respectively.

On the basis of 15 randomly selected plants, data were recorded on days to 50 per cent flowering, days to maturity, plant height $(\mathrm{cm})$, number of effective tillers per plant, number of spikelets per spike, number of grains per spike, 1000-grain weight (Test weight) (g), biological yield per plant $(\mathrm{g})$, harvest index (\%) and grain yield per plant (g). Data recorded on above quantitative traits were subjected to statistical analyses fallowing analysis of variances Sukhatme (1967), heritability in broad sence $\left(\mathrm{H}_{\mathrm{bs}}\right)$ and genetic advance (GA) (Robinson et al., 1949).

\section{Results and Discussion}

Analysis of variance for the design of experiments revealed that mean squares due to treatments were highly significant for all the ten characters studied (Table 1). The existence of genetic variability in the population provides ample opportunities for selection being effective.

The pool of genotypes was therefore, assessed for variability analysis. The existence of wide diversity among the constituent genotypes with regard to characters under study was confirmed through various statistical parameters. The basic material, therefore, offers positive opportunities for investigation furtherance of the aforesaid objectives. The estimates of mean, range, variability, heritability (Broad sense) and genetic advance in per cent of mean presented for both $F_{1}$ and $\mathrm{F}_{2}$ generations in table 2 .

The grain yield per plant among parents ranged from (5.97 and 6.13g) DBW 17 to (9.78 and 9.56) NW 5054 in both $F_{1}$ and $F_{2}$ generations, respectively, while among crosses, ranged from 10.62 (K 8027 X NW 1014 ) to 16.16 (NW $5054 \mathrm{X} \mathrm{K} 911$ ) in $\mathrm{F}_{1}$ and from 5.89 (DBW 17 X K 911) to 10.08 (HPW $355 \mathrm{X}$ NW 1067) in $\mathrm{F}_{2}$ generation.

The high estimates of phenotypic and genotypic coefficient of variation (>20\%) were recorded for grain yield per plant and biological yield per plant only in $F_{1}$ generations. The characters which exhibited moderate estimates (10-20\%) of PCV and GCV were grain yield per plant and biological yield per plant and number of spikelets per spike exhibited moderate PCV in $\mathrm{F}_{1}$ generation only.

Whereas, number of effective tillers per plant and plant height in both $F_{1}$ and $F_{2}$ generations. Rest of the characters showed low estimates $(<10 \%)$ of PCV and GCV in both $\mathrm{F}_{1}$ and $\mathrm{F}_{2}$ generations. These findings were in conformity with finding of Panwar and Singh (2000), Kumar et al., (2003), Cheema et al., (2006) and Nagireddy and Jyothula (2009). High estimate of heritability in broad sense (>75\%) was recorded for all the characters except for number of effective tillers per plant (73.90 and 49.57\%) and harvest index (37.12 and 51.33) in both $F_{1}$ and $F_{2}$ generations.

The high estimates of heritability was observed for plant height (97.70 and 97.55\%) followed by 1000 grain weight (96.59 and $96.58 \%)$, days to maturity (96.21 and 95.54\%) grain yield per plant (93.85 and $80.33 \%)$ in both $F_{1}$ and $F_{2}$ generations. 
Table.1 Analysis of variance for 10 characters in wheat (Parents, $\mathrm{F}_{1}$ 's and $\mathrm{F}_{2}$ s $\mathrm{s}$ )

\begin{tabular}{|c|c|c|c|c|c|c|}
\hline \multirow{4}{*}{ Characters } & \multicolumn{6}{|c|}{ Sources of variation } \\
\hline & \multirow{2}{*}{\multicolumn{2}{|c|}{$\begin{array}{c}\text { Replications } \\
2\end{array}$}} & \multirow{2}{*}{\multicolumn{2}{|c|}{$\begin{array}{c}\text { Treatments } \\
63\end{array}$}} & \multirow{2}{*}{\multicolumn{2}{|c|}{\begin{tabular}{|l} 
Error \\
126
\end{tabular}}} \\
\hline & & & & & & \\
\hline & $F_{1}$ & $\mathbf{F}_{2}$ & $F_{1}$ & $F_{2}$ & $F_{1}$ & $\mathbf{F}_{2}$ \\
\hline Days to $50 \%$ flowering & 1.52 & 1.91 & $47.26 * *$ & $34.48 * *$ & 1.16 & 1.11 \\
\hline Days to maturity & 0.28 & 1.96 & $88.95 * *$ & $74.75 * *$ & 1.16 & 1.14 \\
\hline Plant height $(\mathrm{cm})$ & 2.10 & 0.17 & $245.41 * *$ & $249.21 * *$ & 1.91 & 2.07 \\
\hline Effective tillers per plant & 0.50 & 0.01 & $2.23 * *$ & $0.64 * *$ & 0.23 & 0.16 \\
\hline Spikelets per spike & 0.26 & 0.23 & $10.81 * *$ & $3.63 * *$ & 0.44 & 0.30 \\
\hline Grains per spike & 1.39 & 0.47 & $58.68 * *$ & $16.38 * *$ & 3.68 & 2.08 \\
\hline 1000 seed weight $(\mathrm{g})$ & 0.10 & 0.42 & $26.13 * *$ & $21.51 * *$ & 0.30 & 0.25 \\
\hline Biological yield per plant $(\mathrm{g})$ & 15.78 & 0.83 & $145.16^{* *}$ & $23.24 * *$ & 5.97 & 3.23 \\
\hline Grain yield per plant $(\mathrm{g})$ & 0.71 & 0.62 & $22.92 * *$ & $3.61 * *$ & 0.49 & 0.27 \\
\hline Harvest index (\%) & 1.79 & 0.30 & $3.70^{* *}$ & $4.63^{* *}$ & 1.33 & 1.11 \\
\hline
\end{tabular}

$*$, ** Significant at $5 \%$ and $1 \%$ probability levels, respectively

Table.2 Estimate of range, mean, coefficient of variation (PCV and GCV), heritability and genetic advance for 10 characters in wheat ( $\left.\mathrm{F}_{1} \& \mathrm{~F}_{2}\right)$

\begin{tabular}{|c|c|c|c|c|c|c|c|c|c|}
\hline \multirow{2}{*}{ Characters } & & \multirow{2}{*}{$\begin{array}{c}\text { General mean } \\
\pm \mathrm{SE}\end{array}$} & \multicolumn{2}{|c|}{ Range } & \multicolumn{2}{|c|}{ Coefficient of variation $(\%)$} & \multirow{2}{*}{$\begin{array}{c}\text { Heritability in } \\
\text { broad sense } \\
(\%)\end{array}$} & \multirow{2}{*}{$\begin{array}{c}\text { Genetic } \\
\text { advance }\end{array}$} & \multirow{2}{*}{$\begin{array}{c}\text { Genetic } \\
\text { advance in per } \\
\text { cent of mean }\end{array}$} \\
\hline & & & Parents & Crosses & Phenotypic & Genotypic & & & \\
\hline \multirow{2}{*}{ Days to $50 \%$ flowering } & $\mathbf{F}_{1}$ & $90.14 \pm 0.62$ & $75.33-97.67$ & $83.67-95.00$ & 4.51 & 4.35 & 92.97 & 7.79 & 8.64 \\
\hline & $\mathbf{F}_{2}$ & $87.68 \pm 0.61$ & $78.67-97.00$ & $83.67-92.67$ & 3.99 & 3.80 & 90.93 & 6.59 & 7.47 \\
\hline \multirow{2}{*}{ Days to maturity } & $\mathbf{F}_{1}$ & $122.64 \pm 0.62$ & $117.00-135.67$ & $119.00-137.67$ & 4.41 & 4.32 & 96.219 & 6.29 & 8.73 \\
\hline & $F_{2}$ & $128 \pm 0.62$ & $115.67-134.00$ & $116.00-134.67$ & 4.13 & 4.04 & 95.54 & 2.52 & 9.97 \\
\hline \multirow{2}{*}{ Plant height } & $F_{1}$ & $85.28 \pm 0.80$ & $68.56-109.85$ & $75.96-114.81$ & 10.20 & 10.08 & 97.70 & 8.83 & 20.53 \\
\hline & $F_{2}$ & $45.64 \pm 0.83$ & $67.13-105.01$ & $68.01-11.72$ & 10.77 & 10.64 & 97.55 & 7.24 & 21.65 \\
\hline \multirow{2}{*}{ Effective tillers per plant } & $\mathbf{F}_{1}$ & $4.23 \pm 0.28$ & $3.60-5.33$ & $3.73-7.20$ & 18.53 & 15.93 & 73.90 & 0.56 & 28.22 \\
\hline & $F_{2}$ & $16.38 \pm 0.23$ & $3.60-4.87$ & $3.40-5.13$ & 13.44 & 9.46 & 49.57 & 0.34 & 13.72 \\
\hline \multirow{2}{*}{ Spikelets per spike } & $\mathbf{F}_{1}$ & $18.58 \pm 0.38$ & $14.93-19.53$ & $16.27-22.73$ & 10.62 & 10.00 & 88.62 & 4.21 & 19.40 \\
\hline & $\mathbf{F}_{2}$ & $42.41 \pm 0.31$ & $14.47-19.73$ & $13.60-19.73$ & 7.24 & 6.43 & 78.88 & 4.45 & 11.77 \\
\hline \multirow{2}{*}{ Number of Grains per spike } & $\mathbf{F}_{1}$ & $47.87 \pm 1.10$ & $40.67-50.52$ & $41.83-56.75$ & 9.80 & 8.94 & 83.23 & 22.82 & 16.81 \\
\hline & $\mathbf{F}_{2}$ & $39.14 \pm 0.83$ & $38.60-50.83$ & $37.00-50.63$ & 6.17 & 5.15 & 69.56 & 11.96 & 8.84 \\
\hline \multirow{2}{*}{1000 seed weight (g) } & $\mathbf{F}_{1}$ & $39.80 \pm 0.31$ & $14.01-45.22$ & $32.97-47.01$ & 7.50 & 7.37 & 96.59 & 0.09 & 14.93 \\
\hline & $\mathbf{F}_{2}$ & $19.81 \pm 0.29$ & $33.92-45.18$ & $32.74-45.50$ & 6.92 & 6.80 & 96.58 & 0.12 & 13.77 \\
\hline \multirow{2}{*}{ Biological yield plant ${ }^{-1}(\mathrm{~g})$} & $\mathbf{F}_{1}$ & $29.31 \pm 1.41$ & $14.86-23.95$ & $26.37-41.64$ & 24.68 & 23.23 & 88.60 & 15.45 & 45.05 \\
\hline & $\mathbf{F}_{2}$ & $25.03 \pm 1.03$ & $14.48-23.88$ & $14.29-24.25$ & 15.88 & 13.03 & 67.33 & 11.57 & 22.63 \\
\hline \multirow{2}{*}{ grain yield plant ${ }^{-1}(\mathrm{~g})$} & $\mathbf{F}_{1}$ & $11.86 \pm 0.40$ & $5.98-9.78$ & $10.62-16.17$ & 23.78 & 23.04 & 93.85 & 28.42 & 45.99 \\
\hline & $\mathbf{F}_{2}$ & $8.13 \pm 0.30$ & $6.14-9.56$ & $5.90-10.09$ & 14.46 & 12.96 & 80.33 & 15.75 & 23.93 \\
\hline \multirow{2}{*}{ Harvest index $(\%)$} & $F_{1}$ & $40.64 \pm 0.67$ & $39.25-42.40$ & $38.80-42.81$ & 3.58 & 2.18 & 37.12 & 13.02 & 2.74 \\
\hline & $\mathbf{F}_{2}$ & $41.21 \pm 0.61$ & $40.16-44.26$ & $38.58-43.31$ & 3.67 & 2.63 & 51.33 & 6.03 & 3.88 \\
\hline
\end{tabular}


The high estimate of genetic advance in per cent of mean $(>20 \%)$ was observed in grain yield per plant (45.99 and 23.93\%) followed by biological yield per plant $(45.05$ and $22.63 \%)$, plant height (20.53 and $21.65 \%)$ in both $F_{1}$ and $F_{2}$, whereas, number of effective tillers per plant $(28.22 \%)$ inF $_{1}$ generation only. Moderate estimate of genetic advance in per cent of mean $(>10 \%-<20 \%)$ was observed for number of spikelts per spike (19.40 and $11.77 \%$ ) followed by 1000-grain weight (14.93 and $13.77 \%$ ) in both $F_{1}$ and $F_{2}$ generation, while number of grains per spike in $\mathrm{F}_{1}$ generation only. High heritability coupled with high estimate of genetic advance in per cent of mean was observed for plant height, and grain yield per plant in both $F_{1}$ and $F_{2}$ generation, while biological yield per plant in $\mathrm{F}_{1}$ generation only. High heritability coupled with moderate estimate of genetic advance in per cent of mean was recorded for all the characters except days to 50 per cent flowering, days to maturity, and harvest index in both $F_{1}$ and $F_{2}$ generation, whereas, number of grains per spike in $F_{1}$ generation which exhibited high or low heritability coupled with low genetic advance in per cent of mean, which in fact demonstrated the presence of additive gene effects indicating effectiveness of selection for improvement of these traits. High heritability coupled with moderate genetic advance was obserwed for only harvest index. Similar finding were reported by Kisana et al., (1982), Abid and Mohammad (1993), Prasad et al., (2006), Saxena et al., (2007), Yousaf et al., (2008), Rahman et al., (2008), Nagireddy and Jyothula (2009). High to medium values of heritability estimates were found associated with moderate expected and actual gain in the most traits. These obtained results indicated that, these traits could be used in the early generation, but would be more effective if postponed to late generation (Kaumber and Gammaal, 2012).

\section{References}

Abid, and Mohammad (1993). Inheritance and inter-relationship studies of some quantitative characteristics in wheat. Pak. J. of Agril. Res; 14 (2/3): 121-125.

Cheema, N. M.; Mian, M. A.; Muhammad and Abid (2006). Studies on variability and some genetic parameters in spring wheat. Pak. J. of Agric. Sci., 43 (1/2): 32-35.

Kisana,N. S.; Chaudhry, A. R.; Mohammad, Tahir and Chaudhary, M. A. (1982). Heritability of some quantitative characters in five crosses of wheat (Triticum aestivum). Pak. J. of Agril. Res., 3 (4): 211-214

Kumar, S.; Dwivedi, V. K. and Tyagi, N. K. (2003). Genetic variability in some metric traits and its contribution to yield in wheat (Triticum aestivum L.) Prog. Agril., 3 (1-2): 152-153.

Nagireddy, A. V. and Jyothula, D. P. B. (2009). Heritability and interrelationship of yield and certain agronomic traits in wheat. Res. on Crops., 10 (1): 124-127.

Panse, V. G. and Shukhatme, P. V. (1967). Statistical methods for Agricultural workers, II ${ }^{\text {nd }}$ Ed. ICAR, New Delhi, 381.

Panwar, B. S. and Singh, D. (2000). Genetic variability and correlation studies in wheat. Indian J. Plant Genet. Resources., 13 (3): 286-289.

Saxena, Payal.; Rawat, R. S.; Verma, J. S. and Meena, B. K. (2007). Variability and association analysis for yield and quality traits in wheat. Pant. J. of Res., 5 (2): 85-92.

Prasad, J.; Kerketta, V.; Prasad, K. D. and Verma, A. K. (2006). Study of genetic parameters under different environmental conditions in wheat (Triticum aestivum L.) J. of Res. Birsa Agril. Uni., 18 (1): 135-140 
Rahman, M. A.; Shamsuddin, A. K. M.; Sadat, M. A.; Sarkar, M. A. and Khan, A. S. M. M. R. (2008). Estimation of heritability and genetic advance for yield contributing characters of wheat grown under optimum and late sowing condition. Ann.of Bangladesh Agric., 12 (1): 11-20.

Robinson, H. F.; Comstock, R. E. and Harvey, P. H. (1949). Estimation of heritability and the degree of dominance in corn. Agron. J., 41: 353-359.

Yousaf Ali.; Atta, B. M.; Javed, Akhter; Monneveux, P. and Zahid L. (2008). Genetic variability, association and diversity studies in wheat (Triticum aestivum L.) germplasm. Pak. J. of Botany, 40 (5): 2087-2097.

\section{How to cite this article:}

Deepak Kumar, R.K. Srivastava, P.K. Yadav, Ashwani Kumar and Yadav, R.S. 2017. Studies on Variability, Heritability and Genetic Advance in Some Quantitative Characters in Bread Wheat (Triticum aestivum L.). Int.J.Curr.Microbiol.App.Sci. 6(7): 873-877. doi: https://doi.org/10.20546/ijcmas.2017.607.107 